\title{
HUBUNGAN KORELATIF HUKUM DAN MASYARAKAT DITINJAU DARI PERSPEKTIF SOSIOLOGI HUKUM
}

\author{
Roseffendi \\ Kepala Bagian Bantuan Hukum Pemerintah Provinsi Bengkulu \\ Jln. Pembangunan Padang Harapan Kota Bengkulu \\ Email: roseffendi@gmail.com
}

\begin{abstract}
Legal causes are not relevant to the reality of society because the existing law is formed in a top-down manner, which comes from the will of the elite (the ruler), while the community is the target object. Even though the law can be responsive, the law must be formed in a bottom-up manner from the reality that lives in the community. The results of the study can be concluded that the usefulness of the sociological perspective in analyzing legal issues (legal sociology) is, among others: Legal sociology is useful for providing capabilities for understanding the law in a social context, Mastery of sociological concepts of law can provide capabilities to conduct analysis of the effectiveness of law in society, both as a means of social control, a means to change society and a means to regulate social interactions, to achieve certain social conditions, and legal sociology provide possibilities and the ability to evaluate the effectiveness of law in society .
\end{abstract}

\section{Keywords: Law, Society, Sociology of Law}

\begin{abstract}
Abstraks: Penyebab hukum tidak relevan dengan kenyataan masyarakat dikarenakan hukum yang ada dibentuk secara top-down yaitu berasal dari kehendak kaum elit (penguasa), sedangkan masyarakat adalah obyek sasaran. Padahal agar hukum dapat berlaku secara responsif maka hukum harus dibentuk secara bottom-up dari kenyataan yang hidup dalam masyarakat. Hasil penelitian dapat disimpulkan bahwa kegunaan perspektif sosiologi dalam menganalisa permasalahan hukum (sosiologi hukum) yaitu antara lain: Sosiologi hukum berguna untuk memberikan kemampuan-kemampuan bagi pemahaman terhadap hukum di dalam konteks sosial, Penguasaan konsep-konsep sosiologi hukum dapat memberikan kemampuan-kemampuan untuk mengadakan analisa terhadap efektivikasi hukum dalam masyarakat, baik sebagai sarana pengendalian sosial, sarana untuk merubah masyarakat dan sarana untuk mengatur interaksi sosial, agar mencapai keadaa-keadaan sosial tertentu, dan Sosiologi hukum memberikan kemungkinan-kemungkinan serta kemampuan untuk mengadakan evaluasi terhadap efektivitas hukum di dalam masyarakat.
\end{abstract}

Kata Kunci: Hukum, Masyarakat, Sosiologi Hukum 
AL-IMARAH: Jurnal Pemerintahan dan Politik Islam Vol. 3, No. 2, 2018

Pendahuluan

Realita sosial yang terjadi di tengah masyarakat (das sein) terkadang tidak sesuai dengan yang diharapkan seharusnya terjadi (das sollen). Demikian juga dengan hukum sebagai norma yang seharusnya diikuti atau dilaksanakan terkadang tidak dapat berjalan sesuai dengan harapan, baik disebabkan norma tersebut memang tidak dapat diterapkan karena tidak relevan dengan kenyataan yang hidup dalam masyarakat atau dikarenakan perilaku masyarakat yang membuat hukum tersebut tidak ditaati.

Penyebab hukum tidak relevan dengan kenyataan masyarakat dikarenakan hukum yang ada dibentuk secara top-down yaitu berasal dari kehendak kaum elit (penguasa), sedangkan masyarakat adalah obyek sasaran. Padahal agar hukum dapat berlaku secara responsif maka hukum harus dibentuk secara bottom-up dari kenyataan yang hidup dalam masyarakat.

Mengacu dari asal atau sumber bahan dan proses pembentukan hukum tersebut, terdapat dua tradisi hukum yaitu tradisi hukum yang bersifat top-down dan tradisi hukum yang bersifat bottom-up. Tradisi yang bersifat topdown memiliki konsekuensi penekanan pada hukum tertulis yang banyak dianut oleh negara-negara eropa kontinental dengan sistem hukum civil law. Sedangkan tradisi yang bersifat bottom-up memiliki kecendrungan untuk lebih mengutamakan hukum kebiasaan yang hidup dari perilaku umum masyarakat, yang pada umumnya dianut negara-negara 190 anglo saxon dan anglo amerika dengan sistem hukum common law.

Di antara dua sistem hukum tersebut, Indonesia memiliki kecendrungan mengikuti sistem hukum civil law. Hal ini dapat dilihat dari sumber hukum formil yang utama di Indonesia yaitu peraturan perundangundangan, yang notabene peraturan tertulis yang dibuat para elit parlemen. Secara historis, pengaruh civil law menjadi tradisi sistem hukum Indonesia sejak zaman penjajahan Belanda yang membawa pengaruh civil law system dan secara perlahan menghilangkan tradisi asli sistem hukum Indonesia yang menjunjung tinggi adat dan kebiasaan masyarakat. Akibat dari sistem hukum tersebut, seringkali ditemukan gap antara das sollen dan das sein. Hal ini dapat dilihat dari banyaknya peraturan perundang-undangan yang tidak berlaku efektif dan tidak lebih dari sekedar rumusan kata-kata yang tidak mengandung kekuatan normatif untuk ditaati.

Untuk mencari dan menemukan solusi terhadap keberlakuan hukum secara efektif tidak lain dengan cara kembali menggali hubungan korelatif antara hukum dan masyarakat, Hal ini mengingat bahwa hukum untuk masyarakat, dan masyarakat membutuhkan hukum dalam menata kehidupan sosial, bukan masyarakat untuk hukum. Dalam rangka mengetahui hubungan korelatif tersebut tidak dapat dilepaskan dari peran sosiologi hukum. Pada pokoknya perspektif sosiologi merupakan instrumen untuk menganalisa harmonisasi penerapan 
Roseffendi:

Hubungan Korelatif Hukum Dan Masyarakat Ditinjau Dari Perspektif Sosiologi Hukum

hukum dalam konteks law in book dan law in action atau antara das sollen dan das sain.

\section{Pembahasan}

\section{A. Masyarakat dan Hukum}

Manusia tunggal adalah manusia pribadi, merupakan satu keutuhan atau satuan yang menjadi sumber dan transformator dari segala kegiatan. Sebagai subyek dari nilai-nilai tertentu, ia melakukan tindakan-tindakan untuk memenuhi segala apa yang berharga bagi hidupnya karena dorongan batinnya. Dan itu pada asasnya bebas dan merdeka. Di sinilah letaknya sumber asal-usul yang dalam abad sekarang dilaksanakan dan disebut "hak-hak kebebasan dasar manusia". Akan tetapi manusia tidak dapat hidup sendirian di dunia ini. Senantiasa ia hidup bersama-sama dengan manusia lain di mana ia mendapati dirinya dalam suatu masyarakat. Masyarakat sebagai suatu partner of independent relation, suatu kenyataan merupakan suatu gegebenheit di pelosok manapun di dunia ini. ${ }^{1}$

Berdasarkan pendapat tersebut, dapat dipahami bahwa pada awalnya manusia adalah mahkluk individu. Sebagai mahkluk individu manusia mempunyai sifat ego, oto cosmis, mementingkan diri sendiri, mempunyai kepentingan dan kehendak, serta mempunyai hak atau kebebasan sebagai sifat yang tidak terpisahkan dari hakikat manusia. Namun kepentingan tersebut tidak akan pernah terpenuhi tanpa melakukan interaksi dan kerjasama dengan manusia lainnya. Melalui kerjasama, manusia saling membantu dan saling mengisi. Oleh karena itu interaksi adalah suatu kebutuhan manusia dalam mencapai kepentingan atau tujuan hidupnya, sehingga selain manusia diartikan sebagai mahkluk individu, manusia disebut juga sebagai mahkluk sosial (zoon politicon). Dengan demikian, manusia yang utuh adalah manusia yang dapat menempatkan diri sebagai mahkluk individu dan mahkluk sosial secara harmonis dalam dirinya.

$$
\text { Mengingat akan banyaknya }
$$

kepentingan, tidak mustahil terjadi konflik atau bentrokan antara sesama manusia, karena kepentingannya saling bertentangan. Gangguan kepentingan atau konflik haruslah dicegah atau tidak dibiarkan berlangsung terus, karena akan mengganggu keseimbangan tatanan masyarakat. Oleh karena itu, keseimbangan tatanan masyarakat yang terganggu haruslah dipulihkan ke keadaan semula (restitutio in integrum=kembali ke keadaan semula). ${ }^{2}$
${ }^{2}$ Sudikno Mertokusumo, "Mengenal Hukum Suatu Pengantar”, Yogyakarta: Liberty, 2003, h. 3 
AL-IMARAH: Jurnal Pemerintahan dan Politik Islam Vol. 3, No. 2, 2018

Di mana ada kontak antar manusia dalam masyarakat diperlukan perlindungan kepentingan. Terutama apabila terjadi konflik barulah dirasakan kebutuhan akan perlindungan kepentingan. Perlindungan kepentingan itu tercapai dengan terciptanya pedoman atau peraturan hidup yang menentukan bagaimana manusia harus bertingkah laku dalam masyarakat agar tidak merugikan orang lain dan diri sendiri. Pedoman, patokan atau ukuran untuk berperilaku atau bersikap dalam kehidupan bersama ini disebut hukum. ${ }^{3}$ Dalam konteks tersebut, hukum berfungsi sebagai alat mewujudkan keamanan dan ketertiban (rust en orde) serta dipandang juga sebagai sebagai alat rekayasa sosial (tool of social enginering) guna menuju social welfare. Roscoe Pond sebagaimana dikutip Ade Maman Suherman menegaskan bahwa hukum harus melayani masyarakat dengan mengenal dan menyeimbangkan kepentingan antarwarga masyarakat. ${ }^{4}$

Adanya unsur interaksi menunjukkan bahwa eksistensi hukum hanya ada di tengah-tengah masyarakat. Dengan demikian dapat disimpulkan bahwa "di mana ada masyarakat di situ ada hukum" seperti ungkapan Tulieus Cicero (106-45 SM) seorang filsuf

\footnotetext{
${ }^{3}$ Ibid, h. 4

Ade Maman Suherman, "Pengantar
} Perbandingan Sistem Hukum”, Jakarta: Rajawali Pers, 2008, h.. 8-9
Romawi dengan teorinya "ubi societes $i b i$ ius” yang menembus ruang dan waktu. Dengan demikian, hukum merupakan cerminan kepentingan manusia. ${ }^{5}$ Teori Cicero tersebut di atas didukung pula oleh Van Apeldorn dengan teorinya bahwa, "hukum tidak terbatas, melainkan terdapat di mana-mana". 6 Dengan demikian, menurut Von Savigny dalam Satjipto Rahardjo, "es ist und wird mit dem voelke”, hukum akan terus menerus dibicarakan selama kehidupan manusia masih ada. ${ }^{7}$

Berdasarkan uraian tersebut di atas, terlihat jelas hubungan korelatif yang sangat erat antara manusia, masyarakat dan hukum. Hukum lahir dari kehendak manusia untuk menciptakan kondisi sosial yang aman, damai, dan tertib agar tujuannya mudah dicapai. Begitupun sebaliknya, hukum yang merupakan cerminan kehendak manusia tersebut mempunyai peranan penting dalam melindungi manusia dari segala kemungkinan buruk yang timbul akibat interaksi yang terjadi. Artinya, hukum berfungsi sebagai sarana untuk mewujudkan keamanan dan ketertiban (rust en orde), dan juga sebagai alat

\footnotetext{
${ }^{5}$ Bachsan Mustafa, "Sistem Hukum Indonesia Terpadu”, Bandung: Citra Aditya Bakti, 2003, h. 12

6 Van Apeldorn, "Pengantar Ilmu Hukum", Jakarta: Pradnya Paramita, 1982, h. 18

${ }^{7}$ Satjipto Rahardjo, “(Ilmu) Hukum Dari Abad Ke Abad", dalam Sri Rahayu Oktoberina dan Niken Savitri Ed., "Butir-Butir Pemikiran dalam Hukum" Memperingati 70 Tahun Prof. Dr. B. Arief Sidharta, SH., Bandung: Rineka Aditama, 2008, h. 29
} 
rekayasa sosial (as law the tools of social engginering) di mana hukum dapat mendorong terciptanya suatu keadaan yang dikehendaki.

Perlu digaris bawahi bahwa tidak semua hukum melindungi hak-hak manusia. Ada kalanya hukum justru dijadikan alat legitimasi penguasa terhadap tindakan-tindakannya. Hukum dapat dianalogikan sebuah pedang, ketika pedang itu dipegang oleh orang yang baik maka pedang itu akan digunakan untuk melindungi orang-orang disekitarnya dari tindakan sewenang-wenang pihak lain. Begitupun sebaliknya, ketika pedang itu dipegang oleh orang jahat, maka pedang itu akan digunakan untuk menindas bahkan membunuh orang lain.

\section{B. Masyarakat dan Peraturan Perundang-}

\section{Undangan}

Sudah terlalu sering didengar ujaran ubi societes ibi ius (di mana ada masyarakat di situ ada hukum). Pernyataan yang sederhana, yaitu bahwa manusia adalah mahkluk yang tidak bisa hidup di luar tatanan. Tetapi, pernyataan tersebut tidak membicarakan kerumitan yang ada antara societes dan ius. Tidak tergambarkan bagaimana intensif dan rumit kaitan antara keduanya, apalagi sejak sekarang kita menggunakan yang disebut hukum modern. Jarak antara masyarakat dan hukumnya menjadi makin jauh. $^{8}$ Permasalahan hukum modern dimulai dari penerapan hukum tertulis, di mana masyarakat maupun praktisi hukum di Indonesia terjebak dalam pandangan legalistik-formalistik, sehingga tidak dapat berpaling lagi dari hukum tertulis.

Kendati orang ingin sekali membawa atau memasukan keadilan ke dalam hukum tertulis atau undangundang, tetapi hasilnya lebih banyak bersifat cacat dari pada baik. Memikirkan keadilan dan merumuskannya adalah dua hal yang berbeda jauh. Perumusan sangat terikat dan tergantung pada tersedianya kosa kata, tata bahasa dan lain-lain persyaratan peradaban tertulis. Maka orang pun mengatakan, bahwa hukum itu tidak lebih dari pada suatu language game, permainan atau urusan bahasa. Maka tidak heran manakala ada yang berpendapat, bahwa hukum itu cacat sejak dilahirkan. Memang, memikirkan keadilan dan merumuskannya adalah dua hal yang berbeda. $^{9}$

Portalis sebagaimana dikonstantir oleh Sudikno Mertokusumo, berpendapat bahwa kitab undang-undang meskipun tampaknya lengkap, tetapi tidak pernah rampung, sebab ribuan permasalahan yang tidak terduga akan diajukan kepada hakim. Undang-undang yang sudah

8 Satjipto Rahardjo, "Biarkan Hukum Mengalir" Catatan Kritis tentang Pergulatan Manusia dan Hukum, Jakarta: Kompas, 2008, h. 9

${ }^{9}$ Ibid, h. 85 
AL-IMARAH: Jurnal Pemerintahan dan Politik Islam Vol. 3, No. 2, 2018

ditetapkan itu tidak akan berubah, sedangkan manusia tidak pernah berhenti dan perkembangan itu selalu menimbulkan peristiwa baru. ${ }^{10}$

Sejalan dengan pendapat Portalis tersebut, Bagir Manan dalam Ridwan HR menyatakan bahwa undang-undang hanya merupakan cerminan peristiwa seketika (moment opname) yang memuat ketentuan umum semata dan perubahannya pun membutuhkan proses yang rumit. $^{11}$ Sedangkan kenyataan hidup dalam masyarakat bersifat dinamis mengikuti perkembangan zaman. Oleh karena itu, undang-undang akan selalu tertinggal oleh dinamika sosial, dengan kata lain ketika suatu peraturan itu dibuat, maka sejak saat itu pula peraturan tersebut telah usang ditelan zaman. Akibat lebih lanjut, kepastian hukum yang terkandung dalam peraturan tertulis sering tidak relevan dengan keadilan yang diharapkan masyarakat.

Hukum yang semula adalah instrumen untuk mencapai keadilan, namun dalam perkembangan yang dipengaruhi oleh legalitas formil dari aliran positivistik, secara tidak langsung menjadikan hukum sebagai tujuan. Akibatnya, faktor keadilan dalam penegakan hukum sering dikesampingkan oleh kepastian hukum. Padahal keadilan merupakan tujuan akhir dari sebuah proses hukum.

Keadilan bukan terletak di dalam peraturan perundang-undangan, namun ada dalam perspektif masyarakat. Peraturan perundang-undangan hanya sarana yang mengantarkan manusia mencapai keadilan. Oleh karena itu, dalam pembentukan peraturan perundangundangan kenyataan kemasyarakatan tidak dapat diabaikan, karena menentukan substansi hukum, sebagaimana pernyataan Karl Menheim yang mengatakan bahwa "situation gebundenheit" keadaan menentukan pemikiran dan tindakan. Dengan demikian, idealnya perubahan hukum mengikuti perubahan waktu, perubahan keadaan dan kenyataan yang hidup dan berkembang dalam masyarakat.

Jika suatu materi muatan peraturan perundang-undangan pure berasal dari masyarakat, maka tentu tidak ada alasan bagi seseorang untuk menyatakan bahwa ia tidak tahu adanya hukum yang mengatur bahwa ia tidak boleh melakukan suatu perbuatan tertentu. Bahkan apabila berpegangan kepada asas praesumptio iuris et de iure, bukan saja orang yang dapat dikenai aturan undang-undang, melainkan juga dapat dikenai aturan hukum kebiasaan atau yurisprudensi meskipun orang tersebut tidak mengetahui

\footnotetext{
${ }^{10}$ Sudikno Mertokusumo, “Bab-Bab Tentang Penemuan Hukum”, Yogyakarta: Liberty, 1999, h. 167

${ }^{11}$ Ridwan HR, "Hukum Administrasi Negara", Jakarta: Rajawali Pers, 2005, h. 137 
Roseffendi:

Hubungan Korelatif Hukum Dan Masyarakat Ditinjau Dari Perspektif Sosiologi Hukum

adanya hukum kebiasaan dan yurisprudensi tersebut. ${ }^{12}$

Menurut Bagir Manan, hukum yang baik dalam pembentukannya maupun dalam penegakannya sangat dipengaruhi oleh kenyataan-kenyataan sosial, ekonomi, politik maupun budaya. Meskipun dalam situasi tertentu, diakui hukum dapat berperan sebagai sarana pembaharuan, tetapi dalam banyak hal hukum adalah cerminan masyarakat. ${ }^{13}$ Oleh karena itu dapatlah dikatakan, bahwa penegakan hukum bukanlah semata-mata berarti pelaksanaan perundang-undangan, walaupun di dalam kenyataan di Indonesia kecenderungannya adalah demikian, sehingga pengertian law enforcement begitu populer. Selain itu ada kecenderungan yang kuat untuk mengartikan penegakan hukum sebagai pelaksanaan keputusan-keputusan hakim. Perlu dicatat, bahwa pendapat-pendapat yang agak sempit tersebut mempunyai kelemahan-kelemahan, apabila pelaksanaan perundang-undangan atau keputusan-keputusan hakim tersebut malah mengganggu kedamaian dan ketertiban di dalam pergaulan hidup. ${ }^{14}$

\footnotetext{
12 Peter Machmud, "Pengantar Ilmu Hukum”, Jakarta: Kencana, 2013, h. 262.

13 Bagir Manan, "Penegakan Hukum Yang Berkeadilan”, dalam Majalah Hukum Varia Peradilan Tahun ke XX No. 241 November 2005, h. 10

14 Soerjono Soekanto, "Faktor-Faktor Yang Mempengaruhi Penegakan Hukum”, Jakarta: Rajawali Pers, 2008, h. 7-8
}

Berdasarkan uraian tersebut di atas, dapat dipahami bahwa sesungguhnya hukum itu tidak hanya dipahami sebagai urusan atau masalah peraturan (business of rules) semata. Hukum lebih merupakan masalah manusia dari pada peraturan. Peraturan itu tidak akan menimbulkan berbagai pergolakan dalam hukum apabila tidak digerakkan oleh manusia. Namun di sisi lain, hukum secara tidak langsung dapat mempengaruhi perilaku manusia dan masyarakat dalam berperilaku. Ketika hukum yang ada mengandung sanksi yang berat, maka akan membentuk kecenderungan-kecenderungan

masyarakat untuk taat dan tertib, walaupun ketaatan atau kepatuhan seseorang terhadap hukum tidak selalu disebabkan karena takut akan sanksi, namun ada kalanya seseorang mentaati hukum karena menyadari akan manfaat akan hukum itu sendiri.

C. Perspektif Sosiologis terhadap Budaya Hukum

Secara teoretis, ketaatan masyarakat terhadap hukum akan mempengaruhi keberlakuan hukum. Keberlakuan hukum itu sendiri disebabkan dua hal. Pertama, orang mentaati hukum dikarenakan terpaksa karena takut dijatuhi sanksi. Keberlakuan yang demikian disebut keberlakuan secara normatif. Kedua, orang mentaati hukum dikarenakan menyadari akan manfaat hukum. 
AL-IMARAH: Jurnal Pemerintahan dan Politik Islam Vol. 3, No. 2, 2018

Keberlakuan yang demikian disebut keberlakuan hukum secara sosiologis.

Dari kedua macam keberlakuan hukum tersebut, keberlakuan hukum secara sosiologis yang sangat diharapkan dalam mewujudkan kebermaknaan hukum dalam kehidupan masyarakat.

Keberlakuan hukum secara sosiologis sangat dipengaruhi oleh kesadaran hukum masyarakat, sedangkan kesadaran hukum masyarakat dipengaruhi oleh pemahaman akan hukum, dan pemahaman hukum dipengaruhi oleh pengetahuan hukum. Sementara dalam tradisi hukum Indonesia yang cenderung bersifat legalistik-formalistik dengan mengutamakan hukum tertulis dari pada hukum kebiasaan seperti layaknya penganut tradisi hukum civil law pada umumnya yang menganggap setiap orang tahu hukum sangat mustahil adanya, mengingat tidak semua hukum tertulis (peraturan perundang-undangan) yang dibuat berasal dari kenyataan masyarakat. Justru sebaliknya peraturan perundangundangan dibuat secara top-down dan tidak lebih dari kehendak para elit. Belum lagi keterbatasan kemampuan dalam mensosialisasikan peraturan yang ada. Oleh karena itu, tidak adil jika setiap orang dianggap tahu hukum seperti fictie hukum. Dengan demikian, hukum yang baik adalah hukum yang bukan dibentuk berdasarkan kehendak sepihak dari pemerintah despotik, namun hukum yang dibentuk berdasarkan kehendak orang banyak/masyarakat (volunter general) dan digunakan untuk kepentingan orang banyak untuk mencapai tujuan hukum itu sendiri yaitu keadilan.

Intinya, masalah kesadaran hukum warga masyarakat menyangkut faktorfaktor apakah suatu ketentuan hukum tertentu diketahui, dipahami, ditaati, dan dihargai. Apabila warga masyarakat hanya mengetahui adanya suatu ketentuan hukum, maka taraf kesadaran hukumnya lebih rendah dari mereka yang memahaminya, dan seterusnya. Hal itulah yang disebut legal consciousness atau knowledge and opinion about law.

Menurut Zainuddin Ali, hal-hal yang menentukan kesadaran hukum yaitu: ${ }^{15}$

\section{Pengetahuan Hukum}

Bila suatu perundang-undangan telah diundangkan dan diterbitkan menurut prosedur yang sah dan resmi, maka secara yuridis peraturan perundangundangan itu berlaku. Kemudian timbul asumsi bahwa setiap warga masyarakat dianggap mengetahui adanya undang-undang tersebut

2. Pemahaman Hukum Apabila pengetahuan hukum saja yang dimiliki oleh masyarakat, hal itu belumlah memadai, masih diperlukan pemahaman atas hukum yang berlaku.

15 Zainudi Ali, "Sosiologi Hukum”, Jakarta: Sinar Grafika, 2007, h. 50 
Roseffendi: Hubungan Korelatif Hukum Dan Masyarakat Ditinjau Dari Perspektif Sosiologi Hukum

Melalui pemahaman hukum, masyarakat diharapkan memahami tujuan peraturan perundang-undangan serta manfaatnya bagi pihak-pihak yang kehidupannya diatur oleh peraturan perundangan-undangan dimaksud.

3. Penaatan hukum

Seorang warga masyarakat menaati hukum karena berbagai sebab. Sebabsebab dimaksud, dapat dicontohkan sebagai berikut: ${ }^{16}$

a. Takut karena sanksi negatif, apabila melanggar hukum dilanggar.

b. Untuk menjaga hubungan baik dengan penguasa.

c. Untuk menjaga hubungan baik dengan rekan-rekan sesamanya.

d. Karena hukum tersebut sesuai dengan nilai-nilai yang dianut.

e. Kepentingannya terjamin Secara teoritis, faktor keempat merupakan hal yang paling baik. Hal itu disebabkan pada faktor pertama, kedua, dan ketiga, penerapan hukum senantiasa di dalam kenyataannya.

\section{Pengharapan Terhadap Hukum}

Suatu norma hukum akan dihargai oleh warga masyarakat apabila ia telah mengetahui, memahami, dan menaatinya. Artinya, dia benar-benar dapat merasakan bahwa hukum tersebut menghasilkan ketertiban serta ketenteraman dalam dirinya. Hukum tidak hanya berkaitan dengan segi lahiriah dari manusia, akan tetapi juga dari segi batiniah.

5. Peningkatan kesadaran hukum

Peningkatan kesadaran hukum seyogyanya dilakukan melalui penerangan dan penyuluhan hukum yang teratur atas dasar perencanaan yang mantap. Tujuan utama dari penerangan dan penyuluhan hukum adalah agar warga masyarakat memahami hukumhukum tertentu, sesuai masalah-masalah hukum yang sedang dihadapi pada suatu saat. Penerangan dan penyuluhan hukum menjadi tugas dari kalangan hukum pada umumnya, dan khususnya mereka yang mungkin secara langsung berhubungan dengan warga masyarakat, yaitu petugas hukum.

Jika kesadaran hukum tersebut dianut oleh masyarakat luas, maka akan membentuk suatu budaya hukum yang didalamnya mengandung nilai-nilai yang mendasari hukum yang berlaku seperti nilai ketertiban dan ketentraman, nilai etika, nilai kepastian, nilai kemanfaatan, dan nilai keadilan. Nilai-nilai itulah yang menjadi motivasi setiap orang untuk mentaati hukum, sehingga pada akhirnya hukum dapat berfungsi sebagaimana mestinya dalam mencapai tujuan hukum

${ }^{16}$ Ibid, h. 68. 
AL-IMARAH: Jurnal Pemerintahan dan Politik Islam

Vol. 3, No. 2, 2018

yang paling luhur yaitu keadilan,

kemanfaatan, dan kepastian.

\section{Penutup}

Berdasarkan uraian tersebut di atas, dapat disimpulkan bahwa kegunaan perspektif sosiologi dalam menganalisa permasalahan hukum (sosiologi hukum) yaitu antara lain: ${ }^{17}$

1. Sosiologi hukum berguna untuk memberikan kemampuan-kemampuan bagi pemahaman terhadap hukum di dalam konteks sosial.

2. Penguasaan konsep-konsep sosiologi hukum dapat memberikan kemampuankemampuan untuk mengadakan analisa terhadap efektivikasi hukum dalam masyarakat, baik sebagai sarana pengendalian sosial, sarana untuk merubah masyarakat dan sarana untuk mengatur interaksi sosial, agar mencapai keadaa-keadaan sosial tertentu.

3. Sosiologi hukum memberikan kemungkinan-kemungkinan serta kemampuan untuk mengadakan evaluasi terhadap efektivitas hukum di dalam masyarakat.

\section{Pustaka Acuan}

Ade Maman Suherman, Pengantar Perbandingan Sistem Hukum, (Jakarta: Rajawali Pers, 2008)

Bachsan Mustafa, Sistem Hukum Indonesia Terpadu, (Bandung: Citra Aditya Bakti, 2003)

${ }^{17}$ Soerjono Soekanto, "Pokok-Pokok Sosiologi Hukum”, Jakarta: Rajawali Pers, 1980, h. 30 198
Bagir Manan, "Penegakan Hukum Yang Berkeadilan", (dalam Majalah Hukum Varia Peradilan Tahun ke XX No. 241 November 2005)

Mukthie Fadjar, Tipe Negara Hukum, (Malang: Bayumedia, 2005)

Peter Machmud, Pengantar Ilmu Hukum, (Jakarta: Kencana, 2013)

Ridwan HR, Hukum Administrasi Negara, (Jakarta: Rajawali Pers, 2005)

Satjipto Rahardjo, (Ilmu) Hukum Dari Abad Ke Abad", dalam Sri Rahayu Oktoberina dan Niken Savitri Ed., "Butir-Butir Pemikiran dalam Hukum Memperingati 70 Tahun Prof. Dr. B. Arief Sidharta, SH., (Bandung: Rineka Aditama, 2008)

Satjipto Rahardjo, Biarkan Hukum Mengalir Catatan Kritis tentang Pergulatan Manusia dan Hukum, (Jakarta: Kompas, 2008)

Sudikno Mertokusumo, Bab-Bab Tentang Penemuan Hukum, (Yogyakarta: Liberty, 1999)

Sudikno Mertokusumo, Mengenal Hukum Suatu Pengantar, (Yogyakarta: Liberty, 2003)

Soerjono Soekanto, Pokok-Pokok Sosiologi Hukum, (Jakarta: Rajawali Pers, 1980)

Soerjono Soekanto, Faktor-Faktor Yang Mempengaruhi Penegakan Hukum, (Jakarta: Rajawali Pers, 2008)

Van Apeldorn, Pengantar Ilmu Hukum, (Jakarta: Pradnya Paramita, 1982)

Zainuddin Ali, Sosiologi Hukum, (Jakarta: Sinar Grafika, 2007) 